\title{
METODE TOTAL PHYSICAL RESPON SE (TPR) PADA PENGAJARAN BAHASA INGGRIS SISWA TAMAN KANAK-KANAK
}

\author{
Yuli Astutik, \& Choinun N isak Aulina \\ Universitas Muhammadiyah Sidoarjo \\ Email: yuliastutik@ umsida.ac.id \\ D OI: http:/ / dx.doi.org/ 10.17509/ bs_jpbsp.v17i2.9658
}

\begin{abstract}
Abstrak
Metode TPR adalah salah satu metode untuk pengajaran bahasa pada anak usia dini karena penerapannya berhubungan antara koordinasi perintah, ucapan dan gerak sehingga seorang anak lebih mudah untuk menguasai suatu bahasa dalam pembelajarannya. Tujuan penelitian ini adalah untuk menganalisis bagaimana guru TK Aisyiyah 5 Tanggulangin mengajarkan bahasa Inggris dengan metode TPR pada siswanya. Metode penelitian ini menggunakan desain kualitatif deskriptif. Non partisipan observasi dan wawancara dilakukan sebagai teknik pengumpulan data. Hasil penelitian ini menunjukkan bahwa dari tiga belas aspek metode TPR ditemukan bahwa guru lebih sering mengimplementasikan TPR pada netural conditionsbaik di dalam maupun di luar jam pelajaran. Pada penerapan metode TPR diketahui juga temyata siswa tidak hanya merespon dengan gerakan fisik atau nonvedal saja tapi juga dengan respon ucapan atau vebal. Data wawancara menunjukkan bahwa guru lebih kreatif menggunakan metode TPR dengan tidak terpaku pada satu materi yang diberikan pada jam pelajaran bahasa Inggris namun juga dalam berinteraksi dan berkomunikasi di luar kelas. D engan metode TPR yang diaplikasikan pada kegiatan sehari-hari oleh guru di lingkungan sekolah dapat membuat siswa lebih mudah memahami bahasa Inggris.
\end{abstract}

Kata kunci: metode total physical response; pengajaran bahasa inggris; anak usia dini

\section{TOTAL PHYSICAL RESPONSE (TPR) METHOD IN ENGLISH TEACH ING} FOR EARLY CHILDHOOD

\begin{abstract}
Total physical response (TPR) method is one of the methods for language teaching in early childhood because its application is related to coordination of command, speech and action. So, children are easier to master a language in their learning. The purpose of this research is to analyze how teachers at TK Aisyiyah 5 Tanggulangin teaches English by using TPR method to their students. This research method use qualitative descriptive design. Non-participant observation and interviews are conducted as the data collection techniques. The results of this research indicate that from the thirteen aspects of the TPR method the teachers are more likely to implement TPR in natural conditions both inside and outside of the classroom. In the application of TPR method is also known that students not only respond with physical movement or nonverbal language but also with utterance or verbal response. Interview data shows that teachers are more creative using the TPR method by not fixating on one material given during English language lesson but also in interacting and communicating outside the classroom. By using TPR method which applied in daily activities by teachers in the school environment can make students more easily understand the English.
\end{abstract}

Keywords : TPR method; English teaching; early childhood 


\section{PEN DAH ULUAN}

Banyak aspek yang mempengaruhi perkembangan seorang anak, aspek-aspek tersebut memberikan kontribusi besar terhadap perkembangan anak, antara lain perkembangan motorik, kognitif, sosial, fisik, emosi serta perkembangan bahasa. Berbicara tentang perkembangan bahasa tanpa disadari bahasa merupakan aspek yang memberi kontribusi besar untuk tumbuh kembang anak. Suhartono (2005, p.8) menyatakan bahwa dengan menggunakan bahasa, anak akan dapat tumbuh dan berkembang menjadi manusia dewasa yang dapat bergaul di tengah-tengah masyarakat. Khususnya pada anak usia dini, kemampuan berbahasa dan berkomunikasi merupakan kebutuhan dan merupakan hal esensional untuk awal proses di sekolah. Dengan menguasai bahasa seorang anak mampu berkomunikasi dengan orang-orang disekitamya baik dengan teman sebayanya bahkan dengan orang dewasa, sehingga anak tersebut dapat memperoleh pengetahuan dari apa yang mereka dengar dan mereka ucapkan.

Pembelajaran bahasa tidak hanya sebatas bahasa ibu (bahasa pertama) maupun bahasa kedua, namun juga bahasa asing. Di negara kita, Indonesia, penggunaan bahasa asing dalam hal ini adalah bahasa Inggris sebagai bahasa sehari-hari bukanlah hal yang baru lagi meskipun hanya sebatas kata-kata sapaan (gretings) atau perpisahan (farendl) seperti contoh: goodmoming howareyau, seyal, good bye dan lain sebagainya. Bahkan bahasa Inggris juga masuk pada mata pelajaran di sekolah formal mulai dari Taman Kanak-kanak (TK) hingga Perguruan Tinggi. Berbicara tentang pelajaran bahasa Inggris di sekolah TK tentunya tidaklah mudah, hal ini karena mengajarkan bahasa Inggris pada anak usia dini berbeda dengan mengajarkan bahasa Inggris untuk orang dewasa. Dibutuhkan kesabaran dan ketelatenan dari seorang guru untuk mengajarkan bahasa Inggris kepada siswa TK. Selain itu, dalam menghadapi anak-anak seorang guru harus kreatif dan menyenangkan dalam menyampaikan materinya. Hal tersebut tentunya tidak lepas dari strategi, teknik ataupun metode yang digunakan guru tersebut. Salah satu metode yang menyenangkan untuk mengajarkan bahasa Inggris kepada anak usia dini adalah metode TPR (Total Physical Response).

Beberapa ahli mengemukakan tantang definisi TPR sebagai metode pembelajaran bahasa yang efektif dan menyenangkan terutama untuk diberikan kepada anak usia dini. Metode ini pertama kali dikembangkan oleh James J. Asher yang telah sukses dalam pengembangan metode pembelajaran bahasa asing pada anak-anak. Asher (1968, p.7) mengemukakan bahwa pengucapan langsung pada anak mengandung suatu perintah, sehingga anak tersebut akan merespon dengan fisiknya (body langrage) sebelum mereka memulai untuk menghasilkan respon ucapan (verbal langrage). Sehingga dapat dikatakan bahwa "Total Physical Response (TPR) atau Respon Fisik Total ini merupakan metode pembelajaran bahasa Inggris yang sesuai untuk anak usia dini dimana pembelajarannya lebih mengutamakan kegiatan yang langsung berhubungan dengan kegiatan fisik dan gerakan. Sedangkan menurut Larsen \& Freeman (1986, p.116) "TPR adalah the comprenension approadh atau pendekatan pemahaman yakni metode pendekatan bahasa asing dengan perintah atau instruksi". Richards \& Rodgers (1999, p.87) juga berpendapat bahwa "TPR merupakan suatu metode pembelajaran bahasa yang disusun pada koordinasi perintah (๕mmand), ucapan (speech) dan gerak (adian); dan berusaha untuk mengajarkan bahasa melalui aktivitas fisik (mota)".

Hal ini juga diperkuat oleh Richard (2001, p.73) yang juga menyatakan bahwa Total Physical Response atau Respon Fisik Total merupakan metode pengajaran bahasa yang menggunakan kerjasama ucapan dan gerak tubuh yang merupakan usaha untuk mengajarkan bahasa melalui sebuah aktifitas. Metode TPR merupakan metode pembelajaran bahasa yang berhubungan antara koordinasi perintah, ucapan dan gerak. Sehingga seorang guru berusaha mengajarkan bahasa melalui aktifitas fisik. Begitu juga dengan Tarigan (2009, p.133) yang berpendapat bahwa "dalam metode 
TPR pemahaman dan ingatan diperoleh dengan baik melalui gerakan tubuh para siswa dalam menjawab atau memberikan respon pada perintah-perintah. Bentuk Impeative bahasa merupakan sarana ampuh untuk memanipulasikan tingkah laku para siswa dan membimbing mereka kearah pemahaman melalui gerak atau perbuatan". Rachmawati (2013, p.3) menyatakan bahwa "TPR merupakan metode yang popular untuk mengenalkan kosakata yang berkenaan dengan tindakan atau gerakan bagi anak usia dini".

D ari berbagai definisi TPR di atas dapat disimpulkan bahwa metode TPR merupakan metode yang sangat mudah diaplikasikan dalam pengajaran bahasa karena mengandung unsur gerakan tubuh (moenet) sehingga dapat menghilangkan stress pada anak didik dalam pembelajaran bahasa khususnya pada saat mempelajari bahasa asing yang dalam hal ini adalah bahasa Inggris. Metode TPR juga dapat menciptakan suasana hati yang positif pada anak didik yang dapat memfasilitasi pembelajaran sehingga dapat meningkatkan motivasi siswa dalam mempelajari bahasa target khususnya bahasa Inggris. Di dalam penelitiannya Wijayatiningsih dan Mulyadi (2014, p.65) menyatakan dalam penelitiannya bahwa "penerapan model TPR dapat membantu anak usia dini dalam menguasai kosakata sederhana dalam bahasa Inggris beserta artinya dalam bahasa Indonesia. Penerapan model TPR dalam bahasa Inggris untuk anak usia dini cocok diaplikasikan kepada anak - anak TK". selain itu, Ummah (2017, p.426) menemukan bahwa kebanyakan siswa TK di RA. Nurul Hikmah Pamekasan lebih tertarik untuk belajar bahasa Inggris saat guru meminta mereka untuk mempraktikk ankosakata bahasa Inggris dengan memberi respon secara fisik. Umumnya anak usia dini lebih memilih untuk belajar bahasa Inggris dengan ungkapan sederhana kemudian meniru apa yang dipraktikkan guru baik verbal maupun non verbal (gerakan).

Melihat keberhasilan anak saat mempelajari bahasa di sekolah, tentunya tidak lepas dari peran guru dalam menerapkan metode TPR. Guru merupakan pengarah dan fasilitator di lingkungan sekolah untuk memberikan materi kepada siswanya. Guru yang menentukan tentang apa yang akan dipelajari dan siapa yang memerankan materi pelajaran. Siswa dalam metode TPR ini memiliki peran utama sebagai listener (pendengar) sekaligus adtor (pelaku). Siswa mendengarkan dengan penuh seksama kemudian merespon secara fisik berdasarkan perintah yang diberikan guru baik secara kelompok maupun individu. Berhasil tidaknya penerapan metode TPR untuk mengajarkan bahasa Inggris tidak lepas dari kefasihan guru dalam pengucapan (vedbal) bahasa Inggris maupun keaktifan guru dalam mempraktikkan gerakan (movenent/ adtion).

Larsen \& Freeman (1986, p.116) menyatakan bahwa "metode Total Physical Response yang diterapkan oleh guru bertujuan agar tercipta suasana yang nyaman sehingga siswa dapat menikmati pembelajaran dan dapat belajar untuk berkomunikasi menggunakan bahasa asing dengan baik. Hal ini dikarenakan bahwa pada dasarnya metode ini dikembangkan untuk mengurangi tekanan bagi siswa di dalam kelas, dan membuat suasana kelas menyenangkan". Dengan guru menggunakan metode ini siswa akan sekaligus belajar bahasa sekaligus mempraktikkannya -leaming by daing. Sehingga siswa akan mudah memahami bahasa Inggris yang diajarkan oleh guru. Larsen-Freeman (1986, p.118) juga menyatakan bahwa "pada tahap pertama metode TPR, guru bertindak sebagai model yang memperagakan tindakan. Guru dapat memberikan instruksi pada beberapa anak didiknya dan kemudian memberi contoh atau mempraktekkan ucapannya di hadapan peserta didik agar supaya para peserta didik dapat memahami intruksi atau perintah yang diberikan dan dapat mengikuti ucapak serta gerakan dari instruksi guru. Pada tahap kedua para peserta didik dapat mendemonstrasikan apa yang mereka pahami dari perintah-perintah yang telah diberikan guru. Kemudian sampai pada tahap ketika para peserta didik sudah mengerti, memahami serta merespon perintah atau instruksi secara fisik, para 
peserta didik dapat belajar lebih jauh untuk membaca dan menuliskannya. Sehingga pada saatnya para peserta didik telah siap untuk berbicara dengan bahasa asing.

Menurut Larsen \& Freeman (2000, p.111-113), ada tiga belas aspek di dalam pengajaran metode TPR antara lain: 1) Bahasa target harus disajikan secara utuh, tidak hanya kata demi kata. 2) Pemahaman siswa tentang bahasa target harus dikembangkan sebelum berbicara. 3) Siswa pada awalnya memanggil satu bagian bahasa dengan cepat dengan menggerakkan tubuh mereka. 4) Perintah adalah perangkat linguistik yang kuat dimana guru dapat mengarahkan perilaku siswa. 5) Siswa dapat belajar melalui pengamatan tindakan serta melakukan tindakan sendiri. 6) Sangat penting agar siswa merasa sukses. Perasaan sukses dan rendahnya kecemasan memudahkan pembelajaran. 7) Siswa tidak boleh dihafal rutinitas tetap. 8) Koreksi harus dilakukan dengan cara yang tidak mencolok. 9) Siswa harus mengembangkan fleksibilitas dalam memahami kombinasi baru dari potongan bahasa target. Mereka perlu memahami lebih dari kalimat yang tepat yang digunakan dalam pelatihan. Novelty juga memotivasi. 10) Belajar bahasa lebih efektif bila menyenangkan. 11) Bahasa lisan harus ditekankan dalam bahasa tertulis. 12) Siswa akan mulai berbicara saat mereka siap. 13) Siswa diharapkan membuat kesalahan saat pertama kali mulai berbicara. Guru harus toleran terhadap mereka. Bekerja pada detail bahasa yang bagus harus ditunda sampai siswa menjadi agak mahir.

Pada observasi awal yang dilakukan oleh peneliti di TK Aisyiyah 5 Tanggulangin diketahui bahwa Guru di TK tersebut telah menggunakan Metode Total Physical Response (TPR) dalam mengajarkan bahasa Inggris pada siswanya. Misalnya saat memulai pelajaran setelah mengucap salam, guru memberi stimulasi kepada siswa sebelum dimulainya pelajaran dengan menanyakan aktifitas pelajaran minngu sebelumnya, seperti contoh dibawah ini:
Guru: “ayo anak-anak siapa yang mash ingat pdajaran minggu lalu? Please nise yar hand.."

Murid: "me.. me. me." (sambil mengacungkan tangan)

Penggalan percakapan di atas merupakan contoh aktifitas guru dalam penerapan TPR kepada anak didiknya di TK Aisyiyah 5 Tanggulangin, Sidoarjo. Hal tersebut menunjukkan bahwa saat guru memberi perintah dalam bahasa Inggris dengan kalimat "nise your hand", para siswa merespon dengan mengacungkan tangan mereka. Ini artinya siswa terlebih dahulu telah memahami arti dari kalimat "niseyour hand" yaitu "acungkan tangan" sehingga ada tindakan atau gerakan dimana siswa secara sadar merespon perintah guru dalam bahasa Inggris. Hal ini sejalan dengan salah satu aspek TPR sesuai dengan teori Larsen dan Freeman (2000: 111) yang mengatakan bahwa pemahaman siswa tentang bahasa target harus dikembangkan sebelum berbicara. . Seperti penelitian yang dilakukan oleh Singh (2011, p.21) yang menggunakan indikator Larsen dan Freeman yang menyatakan bahwa siswa merupakan peniru dari contoh gerakan atau non verbal gurunya.

Selama ini beberapa penelitian yang berkaitan dengan metode TPR hanya berfokus meneliti dari sisi siswa terhadap pembelajaran bahasa Inggris dimana siswa hanya merespon command guru dengan respon fisik atau nonvebol languagesaja. O leh karena itu, pada penelitian ini peneliti juga ingin menganalisa bahwa di dalam metode TPR siswa tidak hanya merespon command guru hanya dengan gerakan (non verbal) tapi juga dengan respon ucapan (verbal). Selain itu, peneliti juga fokus meneliti pada sisi guru tentang proses pengajaran bahasa Inggris terhadap anak usia dini. Hal ini karena seorang guru harus memiliki peran aktif dalam menerapkan metode Tdal Physical Response

Berdasarkan kenyataan di atas, dalam penelitian ini peneliti ingin mengetahui lebih dalam tentang penggunan metode Tdal Physical Response (TPR) pada pengajaran bahasa Inggris di TK Aisyiyah 5 
Tanggulangin selain itu peneliti juga ingin menetahui kendala apa saja yang dihadapi guru dan bagaimana cara mengatasi kendala tersebut berdasarkan perspektif guru bahasa Inggris di TK tersebut.

\section{METODE}

Pada penelitian ini peneliti menggunakan metode kualitatif deskriptif. Penelitian ini dilakukan di TK Aisyiyah 5 Tanggulangin kabupaten Sidoarjo Jawa Timur. Alasan peneliti melakukan penelitian di tempat tersebut adalah karena TK Aisyiyah 5 Tanggulangin adalah sekolah Taman Kanakkanak yang telah mengaplikasikan TPR pada pengajaran kosakata bahasa Inggris pada murid-muridnya. Subyek pada penelitian ini adalah Guru bahasa Inggris di TK Aisyiyah 5 Tanggulangin dan siswa TK kelas A. Sedangkan sumber data pada penelitian ini adalah penerapan metode total physical response yang digunakan oleh guru TK Aisyiyah 5 Tanggulangin dalam mengajarkan kosakata bahasa Inggris pada siswanya dan data penelitian ini adalah data verbal maupun nonvebbal yang digunakan guru dan siswa pada saat menerapkan metode TPR dalam mempelajari bahasa Inggris.

Instrumen yang digunakan pada saat pengumpulan data adalah observasi dan wawancara. Di dalam penelitian ini peneliti menggunakan observasi non-partisipan karena disini peneliti tidak secara langsung terlibat di dalam aktifitas pembelajaran bahasa Inggris di dalam kelas maupun interaksi antara guru dan siswa di luar kelas. Peneliti hanya mengamati aktifitas dan interaksi guru dan siswa kelas A. Observasi dilakukan di dalam maupun di luar kelas selama jam sekolah yaitu pukul 8.30 WIB sampai dengan 10.00 WIB setiap hari jumat selama 4 (empat) kali. Sedangkan untuk mendapatkan data yang akurat dan valid, peneliti merekam sumber data dengan video recordar. Selain itu, wawancara juga dilakukan untuk mendapatkan data tambahan. Teknik ini dilakukan untuk memperoleh data dari perspektif guru-guru TK Aisyah 5 Tanggulangin tentang kendala yang dihadapi pada saat menerapkan TPR pada siswa, apa saja penyebab kendala tersebut dan bagaimana cara mengatasinya. Wawancara ini sangat dibutuhkan untuk mengecek kebenaran dari data observasi.

Pada penelitian ini teknik analisa data yang dilakukan adalah mereview data yang telah dikumpulkan, mengidentifikasi aspek-aspek penerapan TPR yang digunakan guru, mengidentifikasi dan melakukan proses reduksi tentang aspek-aspek metode TPR yang muncul ataupun tidak muncul pada pelaksanaan pengajaran bahasa Inggris. Selanjutnya, melakukan review data dari observasi tersebut dengan hasil wawancara untuk mengetahui kendala, penyebab terjadinya kendala dan cara mengatasi kendala tersebut dari perspektif guru. Terakhir adalah membuat kesimpulan berdasarkan analisa data.

\section{HASIL DAN PEMBAHASAN}

Hasil dari observasi dan wawancara menunjukkan bahwa guru TK Aisyiyah 5 menggunakan aspek-aspek metode TPR terhadap siswanya saat mengajarkan kosakata bahasa bahasa Inggris di dalam kelas. Tidak hanya saat proses pembelajaran di dalam kelas, akan tetapi juga guru menggungakan metode TPR saat berinteraksi dengan siswanya di luar kelas. Dari penelitian ini juga diketahui bahwa saat guru memberi command atau perintah di dalam penerapan metode TPR, siswa tidak hanya merespon dengan gerakan fisik atau non vejbal saja tapi juga dengan respon ucapan atau vedbal. Hal ini berbeda dengan beberapa penelitian selama ini yang menyatakan bahwa respon siswa saat guru menerapkan metode TPR hanya dengan respon fisik. Seperti yang dikemukakan oleh Singh (2011, p. 21) bahwa siswa adalah peniru gerakan (non vedbal langrage) gurunya saat guru menerapkan metode TPR. Penjelasan tentang hasil observasi dan wawancara tentang metode TPR pada pengajaran bahasa Inggris di TK Aisyiyah 5 Tanggulangin dijelaskan secara detail sebagai berikut: 


\section{1) Bahasa target harus disajikan secara utuh, tidak hanya kata demi kata.}

Selama ini tidak sedikit guru yang mengajarkan bahasa target yakni bahasa Inggris dengan mengartikan kata demi kata untuk memahami suatu kalimat. Padahal hal tersebut tidak efektif untuk anak dalam mencapai bahasa target. Oleh karena itu, guru diharapkan mampu memberi pengertian dengan bahasabahasa yang lugas dalam mengartikan suatu kalimat dalam bahasa Inggris sekaligus memberi contoh dengan tindakan atau gerak tubuh kepada anak didiknya. Sayangnya hal ini tidak digunakan oleh guru di TK Aisyiayh 5 tanggulangin ini saat pelajaran di dalam kelas. Guru tersebut cenderung hanya mengajarkan satu per satu kata meskipun dalam mengajarkan kalimat sederhana. Seperti contoh penggalan transkrip berikut:

$$
\begin{aligned}
& \text { Guru : "I am a student" apa anak-anak?.. } \\
& \text { helloo students...lihat teacher lihat } \\
& \text { teacher... .apa artinya I? Ayo siapa } \\
& \text { yang tau?? I apa I? }
\end{aligned}
$$

Pada penggalan transkrip di atas memperlihatkan bahwa guru dalam mengajarkan kalimat sederhana di dalam kelas dengan menulisnya di papan dan ia mengartikan kata perkata dari kalimat tersebut. Guru tidak mengajarkan kalimat "I ama sudat" tersebut secara utuh tapi mengartikannya satu demi satu kata tersebut. Contoh lain pada pengamatan di hari yang sama dilakukan oleh peneliti di luar kelas saat jam istirahat, guru terlihat meminta siswa untuk tidak bermain dengan menaiki tangga, guru berkata :"godown pease. ayo turun... " disini guru mengajarkan bahasa Inggris secara utuh dan tidak mengartikannya kata demi kata, yang diikuti tindakan siswa dengan langsung turun dari tangga dan berbisik ke temannya dengan mengucapkan "ehayogodown..godown.."
Ketika hal ini ditanyakan langsung kepada guru pada saat sesi wawancara, guru menjelaskan bahwa ia merasa kesulitan saat harus menerangkan kosakata yang berupa kata benda. Sebaliknya kalau yang diajarkan berupa kata kerja atau perintah, guru tersebut bisa langsung memberi contoh gerakan yang akhirnya dapat dimengerti siswa. Pada aspek yang pertama (1) ini selain respon fisik yang dilakukan siswa terhadap perintah guru, siswa juga merespon secara vedbal atau ucapan dengan mengulang kosakata yang menjadi perintah guru. Seperti penemuan Ummah (2017, p.424) yang menyatakan bahwa "therdeof students were as imitators. It is also one of dharadteistic of TPR method" yang artinya Peran siswa adalah sebagai peniru. Ini juga salah satu karakteristik metode TPR.

\section{2) Pemahaman siswa tentang bahasa target harus dikembangkan sebelum benbicara}

Pada pengamatan di sekolah, sebelum memulai pelajaran bahasa Inggris di kelas guru seringkali meminta siswa untuk selalu mengikuti kosakata yang diucapkannya tanpa terlebih dahulu memberi stimulasi atau memberi pemahaman yang mendalam. Misalnya pada penggalan transkrip pada pengamatan kedua dibawah ini:

Guru : :anak-anak lihat teacher...tahu bahasanya hari dalam bahasa Inggris?"

$$
\begin{aligned}
& \text { Siswa : " belum teacher...." (serentak) } \\
& \text { Guru : " } \text { ok... coba sekarang tirukan } \\
& \text { teacher, Sunday artinya } \\
& \text { minggu.... dst" }
\end{aligned}
$$

Penggalan transkrip di atas mengindikasikan bahwa guru secara langsung meminta siswa untuk mengucapkan kosakata hari dalam bahasa Inggris tanpa terlebih dahulu memberi stimulasi bahwa ada berapa jumlah hari dalam seminggu dan nama -nama hari dalam bahasa Indonesia apakah siswa sudah tahu ataukah belum. Sebaliknya saat 
pengamatan di luar kelas, peneliti menemukan bahwa guru mengaplikasikan aspek metode TPR ini kepada siswa secara individu bahwa guru tersebut memberi pemahaman sebelum kosakata bahasa Inggris diberikan, dan ini sesuai dengan teori Larsen dan Freeman (2000, p.111) bahwa sebelum siswa berbicara ia harus diberi pemahaman tentang bahasa target. Contohnya saat akan pulang dari sekolah, seorang siswa yang berlari keluar kelas dipanggil oleh guru tersebut dan ia menjelaskan kepada siswa untuk bersalaman dahulu terhadap guru, "Ihoo anak ganteng kalau pulang han s salaman dulu sama ibu gunu. shakehand dulu. shake hand apa shake hand?? Salaman..." . penggalan transkrip tersebut menunjukkan bahwa guru memberi pemahaman terlebih dahulu tentang kosakata "bersalaman" dalam bahasa Inggris yang artinya "shakehand" .

Hasil interview memperlihatkan bahwa guru bahasa inggris di TK aisyiyah 5 ini seringkali kehilangan ide yang kreatif untuk memberikan materi terhadap anak didiknya di dalam kelas, bahkan saat harus menghadapi siswa-siswi TK yang pada dasarnya selalu ingin bermain. Sehingga target utamanya adalah hanyan sebatas materi tersampaikan sesuai rencana pelaksanaan pembelajaran harian. Padahal sebenarnya guru bisa lebih mengeksplore kemampuan mengajarnya dengan metode TPR ini, khususnya pada aspek ke dua (2) ini yaitu memberi pemahaman siswa sebelum berbicara, seperti yang ia lakukan saat kegiatan di luar kelas.

\section{3) Siswa diawal mengucapkan satu bagian bahasa dengan cepat dengan menggerakkan tubuh mereka.}

Pada aspek ke tiga (3) ini guru terlihat sangat baik mengaplikasikannya baik di dalam kelas maupun di luar kelas khususnya untuk kata kerja, seperti niseyour hand, shakehand badk off dan lain sebagainya. Seperti contoh ketika beberapa ramai dan berebut meminta bantuan guru untuk mewarnai, guru berkata :" badk off. come on badk off." kemudian para siswa menirukan dengan mengucapkan: "badk off" diikuti dengan bergerak mundur. Begitu juga saat guru meminta siswa untuk duduk, "sit down please. anak-anak sit down please..”, para siswa menirukan kalimat guru dan diikuti dengan gerakan duduk.

Sejalan dengan hasil interview sebelumnya, hal ini dikarenakan guru merasa lebih mudah mengajarkan TPR tentang kata kerja bukan kata benda. Disini sangat perlu kreatifitas guru untuk dapat membuat semua materi dapat dengan mudah diberikan kepada siswa dengan memaksimalkan metode TPR baik itu kata kerja maupun kata benda. Misalnya dengan menunjukkan benda atau gambar benda yang dimaksud.

\section{4) Perintah adalah perangkat linguistik yang kuat dimana guru dapat mengarahkan penilaku siswa.}

Kalimat perintah dengan bahasa target dapat digunakan guru untuk mengarahkan perilaku siswa baik di luar maupun di dalam kelas. Selain contoh kata atau kalimat perintah pada transkrip tentang aspek sebelumnya (2 dan 3), aspek ke empat (4) ini sering digunakan guru TK Aisyiyah 5 Tanggulangin untuk mengarahkan perilaku siswanya di sekolah. Seperti contoh saat siswa ramai dikelas saat guru menerangkan materi pelajaran, sebagaimana transkrip dibawah ini:

$$
\begin{aligned}
\text { Guru : "Anak-anak.. anak-anak... silent } \\
\text { please... look a teacher... look at } \\
\text { teacher... silent please (guru } \\
\text { berbicara sambil meletakkan ujung } \\
\text { jari di mulutnya). } \\
\text { Siswa : (melihat guru dan menirukan } \\
\text { ucapan serta gerakan guru) }
\end{aligned}
$$

Dari transkrip di atas menunjukkan bahwa guru berusaha mengarahkan siswa untuk fokus dan memperhatikan guru menjelaskan materi pelajaran dengan memintanya untuk tenang dan melihat ke depan, Larsen dan Freeman (2000, p.112). Aspek ke empat (4) ini juga seringkali digunakan guru saat berada di luar kelas, misalnya saat jam istirahat berlangsung ada dua siswa yang bertengkar kemudian guru 
melerainya dan mengatakan, "stop... stop. sudah.. begood please. jangan bettengkar...".

Saat hal tersebut diklarifikasi dalam wawancara, guru menerangkan bahwa siswa siswi TK Aisyiyah sudah bisa memahami kalimat-kalimat perintah bahasa Inggris yang digunakan guru untuk komunikasi diluar jam pelajaran. $\mathrm{Hal}$ ini karena guru sering menggunakan istilah-istilah bahasa Inggris saat berinteraksi dengan siswanya untuk komunikasi sehari-hari. Menurut guru tersebut berbicara bahasa inggris pada situasi informal lebih mudah daripada menggunakan bahasa Inggris pada situasi formal khususnya saat penyampaian materi bahasa Inggris di kelas.

\section{5) Siswa dapat belajar melalui pengamatan tindakan serta melakukan tindakan sendiri.}

Pada aspek ini hasil pengamatan yang dilakukan peneliti menunjukkan bahwa siswa dapat belajar melalui tindakan guru yang mereka amati baru kemudian mereka dapat meniru apa yang dikerjakan guru baik di dalam maupun di luar kelas. Saat aktifitas di dalam kelas berlangsung, misalnya ketika guru meminta siswa membuka LK S (lembar kegiatan siswa) dengan bahasa Inggris, seperti :

$$
\begin{aligned}
& \text { Guru : "baik.. sekarang anak-anak... open } \\
& \text { paceten.. mana pageten.?" (guru } \\
& \text { berbicara sambil membuka LKS } \\
& \text { halaman sepuluh). } \\
& \text { Siswa : (Siswa mendengar)... pageten. } \\
& \text { (mengulang perkataan guru) dan } \\
& \text { membuka halaman sepuluh). }
\end{aligned}
$$

Penggalan transkrip di atas jelas mengindikasikan bahwa dengan aspek ke lima (5) metode TPR ini siswa mampu melakukan tindakan setelah melihat tindakan yang dicontohkan guru untuk membuka LKS halaman sepuluh dengan instruksi dengan bahasa Inggris "open pageten."

Guru menjelaskan pada sesi wawancara bahwa siswa-siswi di TK mudah sekali menirukan apa yang mereka lihat. Oleh sebab itu, guru-guru di sekolah tersebut selalu memberi contoh ucapan yang disertai dengan tindakan yang baik di dalam maupun di luar kelas. Khususnya tentang materi bahasa Inggris yang menjadi bahasa target anak didik di sekolah TK Aisyiyah 5 Tanggulangin Sidoarjo, guru lebih sering memberi contoh dengan gerakan atau tindakan untuk mengajarkan bahasa Inggris yang diringi dengan mengucapkan kata perintah atau sebaliknya. Pada hasil penelitiannya Ummah (2017, p.427) juga mengatakan bahwa siswa adalah peniru dari contoh verbal dan non verbel gurunya. Pada proses pembelajaran, fase pertama adalah memberi contoh, pada tahap ini guru memberi perintah kepada siswanya dan memberikan contoh gerakan kepada siswanya. Sehingga siswa akan lebih mudah meniru dan mengingat.

\section{6) Sangat penting agar siswa merasa sukses. Perasaan sukses dan rendahnya kecemasan memudahkan pembelajaran.}

Aspek ke enam (6) berikut ini merupakan aspek yang berhubungan dengan sikap guru dan siswa. Bagaimana guru mengelola kondisi kejiwaan siswa-siswinya agar mereka merasa dapat memahami materi yang telah disampaikannya, kemudian sejauh mana guru dapat membuat siswa merasa sukses dalam memahami materinya. Hal ini sangat diperlukan karena siswa yang merasa dirinya memahami pelajaran yang disampaikan guru akan lebih percaya diri di dalam kelas. Seperti contoh berikut ini:

Guru : "ayoo ... tadi teaher menjelaskan kalau hari senin itu bahasa Inggrisnya... apa anak-anak?

Siswa : Monday.. Monday..

Guru : Excdlent....Istimewa betul sekali... (guru berbicara sambil mengacungkan ibu jari terhadap siswa)

Penggalan transkrip di atas menunjukkan sikap guru yang selalu memotivasi siswa dengan pujian atau apresiasi, sehingga siswa merasa dirinya 
mampu memahami materi yang guru jelaskan. A pabila hal ini terus dilakukan oleh guru, siswa tidak merasa cemas dan stress sehingga suasana yang menyenangkan akan tercipta yang nantinya akan memudahkan pembelajaran bahasa Inggris. Verawati (2016, p.31) dalam penelitiannya mengemukakan bahwa tujuan utama dikembangkan metode TPR adalah untuk mengurangi tingkat strees siswa ketika belajar bahasa asing. Salah satu cara utama adalah untuk menyempurnakan pembelajar berbicara, menguatkan mereka, ketika siswa mulai berbicara, kesempurnaan bukan target utama. Wawancara yang dilakukan peneliti terhadap subyek penelitian yaitu guru bahasa Inggris di sekolah TK ini mengimplementasikan bahwa guru selalu memberi pujian, apresiasi atau komentar yang positif terhadap siswanya. Guru tersebut menyatakan bahwa dalam mendidik anak usia dini harus menghindari kalimat yang negatif, misalnya saat siswa salah menjawab pertanyaan guru. Maka guru tidak mengatakan "itu salah" melainkan "kurang tepat" atau "dont be misy!" menjadi "silent please..." dan lain sebagainya.

\section{7) Siswa tidak boleh menghafal rutinitas tetap}

Siswa tidak diperkenankan melakukan hafalan. Aspek ke tujuh (7) ini tidak ditemukan pada saat guru memberikan materi inti dikelas. Guru bahasa Inggris di sekolah ini didapati memberi materi untuk dihafalkan, misalnya tentang hari, bulan dan warna. Guru juga menanyakan hasil hafalan siswa pada minggu berikutnya.

Ketika diklarifikasi pada sesi wawancara, guru menjelaskan bahwa hal ini dilakukan agar siswa belajar bahasa target di rumah. Seperti yang diketahui usia kanak-kanak merupakan usia emas dimana anak akan dengan mudah memahami dan menghafal sesuatu. Sayangnya hal ini tidak sejalan dengan metode TPR sesuai teori Larsen dan Freeman (2000) bahwa siswa tidak boleh menghafal rutinitas tetap. Artinya mereka harus diberi ruang yag seluas-luasnya untuk belajar bukan untuk menghafal.

\section{8) Koreksi harus dilakukan dengan cara yang tidak mencolok.}

Sejalan dengan aspek ke -enam bahwa siswa harus terus diberi motivasi meskipun mereka membuat kesalahan namun juga tidak membiarkan kesalahan tersebut boleh dilakukan secara terus menerus. Pada saat siswa melakukan kesalahan dalam mengucapkan bahasa target, guru tidak diperkenankan secara terang-terangan menegur atau mengoreksinya yang akan membuat siswa malu dan kehilangan rasa percaya diri. Aspek ini juga digunakan oleh guru TK Aisyiyiah 5 Tanggulangin dengan baik. Tidak menegur secara langsung dan mencolok.

Guru mengatakan bahwa jika hal tersebut dilakukan maka dapat mempengaruhi kondisi psikologis siswa dan menghilangkan rasa percaya diri mereka di hadapan orang lain. Sehingga guru selalu mengoreksi kesalahan siswa dengan menghampiri siswa tersebut dan membantunya untuk memperbaiki kesalahannya. Misalnya saat guru menunjukkan tentang anggota tubuh yaitu hidung, seperti:

$\begin{array}{ll}\text { Guru } & \text { : "Nose."(menunjuk hidung) } \\ \text { Siswa 2 } & \text { : "Nus .." } \\ \text { Guru } & \text { : (guru menghampiri dan } \\ & \text { menunjuk hidung siswa } \\ & \text { tersebut dengan lembut, dan } \\ & \text { mengucapkan hidung dalam } \\ & \text { bahasa inggris).. apa sayang?? } \\ & \text { Nose.." }\end{array}$

Penggalan transkrip di atas merupakan aktifitas guru pada natural setting atau interaksi alami saat di luar jam pelajaran berlangsung. Aspek ke delapan (8) tentang cara guru merespon saat mengetahui siswanya melakukan kesalahan dalam mempelajari bahasa Inggris ini juga sependapat dengan penelitian yang dilakukan oleh Verawati (211, p.32) bahwa guru sebaiknya memberikan toleransi kepada siswa hanya memperbaiki kesalahan secara 
umum. Walaupun harus diperbaiki namun harus secara sopan.

\section{9) Siswa hanus mengembangkan fleksibilitas dalam memahami kombinasi baru dari potongan bahasa tanget. Mereka perlu memahami lebih dari kalimat yang tepat yang digunakan dalam pelatihan. N ovelty juga memotivasi.}

Dalam mengajarkan bahasa Inggris guru dituntut untuk mampu membuat siswa memahami kombinasi tentang potongan kalimat bahasa Inggris serta membuat siswa faham bagaimana menggunakan kalimat yang tepat. Oleh karena itu, novelty atau sesuatu yang baru dan menyenangkan perlu diberikan untuk memotivasi siswa dalam mempelajari bahasa Inggris.

Pada aspek ke sembilan (9) ini, guru bahasa Inggris dikelas A TK Aisyiyah 5 Tanggulangin tampak tidak menggunakannya secara maksimal. Materi yang digunakan cenderung monoton dan justru lebih banyak improvisasi selama interaksi di dalam maupun di luar kelas yang membuat siswa faham dan mampu mengikuti ucapan guru. Saat guru memberi materi inti tentang nama hari dan bulan dengan mengeja huruf-huruf yang ada dipapan lalu kemudian mengucapkan nama nama hari dan bulan tersebut secara serentak, siswa terlihat tegang memperhatikan guru. Sebaliknya saat guru memberi materi tersebut dengan bernyayi, siswa sangat terlihat gembira dan mengikuti ucapan serta gerakan guru menyanyikan lagu tentang nama hari dan bulan.

Aspek ini tidak secara optimal dilakukan guru, seperti dalam penjelasannya pada saat wawancara dengan peneliti. Guru belum dapat mengajarkan kalimat bahasa Inggris secara utuh dan tepat, karena siswa TK ini sebagian masih mengalami kesulitan dalam memahami kosakata. Sehingga untuk membuat siswa termotivasi belajar bahasa Inggris guru selalu memberi hal-hal atau cara baru, contohnya mengajarkan nama-nama hari dan bulan dengan bernyayi dan bergerak.

\section{0) Belajar bahasa lebih efektif bila menyenangkan.}

Pada aspek ke sepuluh (10) ini bernyanyi dan bermain merupakan kegiatan yang dilakukan guru bahasa Inggris di TK Aisyiyah 5 Tanggulangin terhadap siswanya saat pembelajaran di kelas. Guru disekolah ini setiap mengajarkan bahasa Inggris selalu menggunakan teknik bernyanyi dan bermain. Seperti saat menyanyikan lagu tentang nama hari, bulan dan warna dengan bahasa Inggris. Setelah itu biasanya guru selalu meminta siswa untuk mewarnai gambar pada lembar kegiatan siswa sesuai dengan materi yang diberikan.

Dikatakan guru hal ini sangat membantu siswa untuk lebih memahami kosakata bahasa Inggris. Guru menjelaskan bahwa dengan bernyanyi siswa lebih senang untuk belajar bahasa Inggris. Selain bernyayi dan bermain guru juga biasanya mengajak mereka mewarnai. Hal ini juga ditegaskan dengan penemuan Ummah (2017, p.247) dalam penelitiannya bahwa siswa terlihat atraktif dan lebih aktif saat guru memintanya bernyanyi dan bermain saat penerapan metode TPR dalam pengajaran bahasa Inggris.

\section{1) Bahasa lisan hanus ditekankan dalam bahasa tertulis.}

Pada awal pengamatan hingga akhir, peneliti menemukan bahwa guru bahasa Inggris di Tk Aisyiyah 5 ini selalu menggunakan tulisan di papan tulis setiap kali menerangkan materi atau kosakata dalam bahasa Inggris. Setelah mengucapkan kosakata bahasa Inggris, guru menuliskan kosakata tersebut di papan tulis kemudian diikuti semua siswa yang mengucapkan kosakata tersebut dan menulis di lembar kerjanya. Meskipun hal tersebut dilakukan dengan cara yang pelan-pelan, namun siswa terlihat sangat senang dan menikmati sesi menulis yang diberikan guru. 
Dijelaskan guru saat wawancara bahwa menulis dilakukan untuk membantu siswa agar lebih paham dalam mengauasai bahasa Inggris, selain itu menulis juga bagus untuk melatih motorik siswa. Apa yang dilakukan guru ini seiring dengan prinsip Larsen dan Freeman pada aspek ke sebelas (11) ini bahwa pembelajaran bahasa target dengan menggunakan lisan (aral) harus ditekankan dengan penggunakan tulisan (written).

\section{2) Siswa akan mulai berbicara saat mereka siap}

Pada aspek ke dua belas (12) ini guru diharapkan faham tentang kapan siswa siap untuk berbicara bahasa target. Untuk itu guru harus mengetahui perkembangan pembelajaran bahasa setiap siswanya. Aspek ini ternyata juga sudah diimplementasikan oleh guru bahasa Inggris di sekolah TK Aisyiyah 5 ini. Guru tidak memaksa siswa berbicara atau mengucapkan kosakata yang telah diajarkan apabila siswa diketahui belum atau tidak siap. Misalnya saat guru menanyakan hasil hafalan tentang materi sebelumnya, dan ada siswa yang tidak atau masih belum hafal. Maka guru akan mengulas kembali materi tersebut, dan begitu seterunya.

Hal ini disampaikan oleh guru saat peneliti bertanya apakah guru meminta siswa untuk mengucapkan kosakata bahasa Inggris yang mereka belum kuasai. Guru menjelaskan bahwa hal tersebut tidak pernah dilakukan olehnya, yang Ia lakukan adalah jika ada siswa yang belum menguasai atau belum memahami suatu materi berarti siswa tersebut belum siap untuk mengucapkan kosakata tersebut, hal ini ditandai ketika siswa terdiam saat guru bertanya. Maka guru perlu mengulas kembali materi tersebut.

13) Siswa diharapkan membuat kesalahan saat pertama kali mulai benbicara. Guru harus toleran terhadap mereka. Bekerja pada detail bahasa yang bagus harus ditunda sampai siswa menjadi agak mahir.
Aspek ke tiga belas (13) ini berkaitan erat dengan aspek-aspek yang telah dikemukakan oleh Larsen dan Freeman sebelumnya, khususnya aspek ke dua belas. Siswa tidak akan diberi materi lanjutan apabila belum menguasai materi sebelumnya. Guru harus lebih toleran dengan kondisikondisi siswa seperti ini. Aspek ini juga dilakukan oleh guru bahasa Inggris di sekolah TK ini. Guru akan mengulas materi sebelumnya apabila siswa belum mahir dalam mengucapkan bahasa target atau bahasa Inggris.

Dari empat kali pengamatan yang dilakukan, peneliti menemukan bahwa guru hanya memberi 2 materi yaitu pertama tentang nama hari dan bulan, dan yang kedua nama warna. Itu Artinya guru selalu memantapkan memberi materi (hari pertama) pada pertemuan kedua yaitu tentang nama hari dan bulan, sedangkan pada pertemuan ke empat memantapkan materi (hari ketiga) yaitu tentang nama nama warna. Pada aspek ini juga guru tidak diperkenankan memberikan pekerjaan rumah karena materi yang belum benarbenar dikuasai siswa akan mempersulit mereka dalam mengerjakannya. Seperti penelitian yang dilakukan oleh Singh (2011, p.21) bahwa "this method does not require homenork because it is hard when students are at home compleing homenork that they do not undestand"

\section{SIMPULAN}

Merujuk pada hasil penelitian, peneliti memperoleh data bahwa guru bahasa Inggris di TK Aisyiyah 5 Tanggulangin menggunakan aspek-aspek metode TPR baik di dalam kelas maupun di luar kelas pada pengajaran bahasa Inggris terhadap siswanya. Penggunaan metode TPR diketahui lebih optimal digunakan oleh guru pada saat berinteraksi dengan siswa di luar pembelajaran materi bahasa Inggris. Artinya disela-sela memberikan materi di kelas, guru juga seringkali berinteraksi dengan siswa dengan mengaplikasikan metode TPR. Hal ini dapat diketahui pada saat meminta siswa untuk tidak ramai dengan berkata "silent 
pease' sambil meletakkan jari telunjuk di bibir dan sebagainya. Ucapan dan tindakan guru tersebut di respon siswa baik vedbal maupun nonerbal, siswa mengucap silent please dan meletakkan jari telunjuk di bibirnya seolah-olah memberi tahu yang lainnya. Beberapa aspek metode TPR juga seringkali digunakan oleh guru saat berinteraksi dengan siswa di luar kelas atau di luar jam pelajaran, salah satunya seperti kata "stop" untuk menghentikan siswa yang bertengkar. Singkatnya, dari tiga belas aspek metode TPR ditemukan bahwa guru lebih banyak mengimplementasikan TPR pada natural conditions baik di dalam maupun di luar kelas. Data wawancara menunjukkan bahwa guru lebih kreatif menggunakan metode TPR dengan tidak terpaku pada satu materi, sehingga guru dapat mengeksplorasi metode TPR secara optimal seperti mengucapkan kosakata bahasa Inggris yang diikuti dengan gerakan atau action

Dari kesimpulan di atas, implikasi yang dapat dijabarkan dari penelitian ini adalah bahwa metode TPR merupakan cara yang tepat digunakan oleh guru bahasa Inggris tidak hanya dalam mengajarkan materi pokok tentang pembalajaran bahasa Inggris di kelas akan tetapi juga dalam berinteraksi dan berkomunikasi sehari-hari. D engan metode TPR yang diaplikasikan pada kegiatan seharihari oleh guru di lingkungan sekolah dapat membuat siswa lebih mudah memahami bahasa target yang sedang dipelajari.

\section{DAFTAR RUJUKAN}

Asher, J. (1968). Tdal physical response method for second language leaming San Jose: San Jose State College.

Larsen - Freeman, D.(1986). Tedmiques and primiples in language teading NewYork: Oxford University Press

Larsen-Freeman, D., \& Anderson, M..(2000). Tehniques and priniples in language leaming New York: Oxford University Press.
Rachmawati, R., (2013). Penganuh penggunaan motode total physical response (TPR) terhadap pengrasaan kosakata bahasa Inggis anak taman kamak-kanak (penditian kuasi ekspeimen di TK-PG Danul Hikam Bandung. Diakses dari: http:/ / repository.upi.edu.

Richard, J., \& Rodgers, T.(2001). Approadkes and mothoos in langrage teading ( $\left.1^{\text {st }} \mathrm{ed}\right)$. Cambridge: Cambridge University Press

Singh, Jai P. (2011). Effectiveness of total physical response. Acadamic Voices a MultidisaplinaryJoumal, 1(1), p 20-22.

Suhartono.(2005). Pengenbangan keterampilan bicara anak usia dni. Jakarta: D epartemen Pendidikan Nasional.

Tarigan, H.G. (2009). Pengajaran keekibahasaan Bandung: Angkasa

Ummah, S.S. (2017). The Implementation of TPR (Total Physical Response) Method in Teaching English for Early Childhood. Advances in Social Saienes, Education and Humanities Reserch (ASSEHR), Vd.58, p 421-428

Verawati. (2016). Metode respon fisik total. Jumal Metamorosa, 4(2), p 27-34.

Wijayatiningsih, \& Mulyadi. (2014). Pemanfaatan model total physical response dan repetition untuk pengembangan pembelajaran bahasa Inggris anak usia dini/ TK. Jumal Penditian Pendidikan, 31(1), p 63-66.

\section{ACKN OWLEDGEMENTS}

Peneliti mengucapkan terimakasih kepada pihak sekolah dan guru-guru TK Aisyiyah 5 Tanggulangin yang telah menjadi subJek penelitian ini. 